\title{
Urban agriculture in Botswana
}

Commonwealth Journal of Local Governance

Issue 18: December 2015

http://epress.lib.uts.edu.au/ojs/index.php/cjlg

\section{Aloysius Clemence Mosha}

University of Botswana

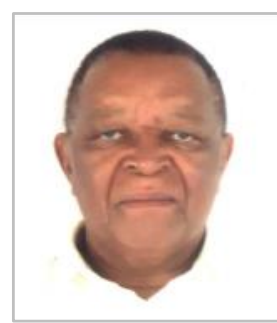

\begin{abstract}
Botswana, a middle-income country, is experiencing a sluggish economic growth and a rapid urbanisation which has brought in its wake high unemployment, poverty and food insecurity. This has led some people to engage in subsistence and commercial urban and peri-urban agriculture (UPA) to address these problems. However, in spite of its known advantages, uptake of UPA has been low for a number of reasons including: high GDP before the economic meltdown of recent years; a harsh climate; lack of water; poor access to land; and over-reliance on generous government handouts. Nevertheless, the extent of its practice and its contribution to food security - albeit modest - shows that it is a sector that needs to be encouraged and supported. Both central and local government can play a big role by providing land and infrastructure, and also by implementing an enabling policy and regulatory environment which promotes small-and medium-scale urban food production.
\end{abstract}

\section{Introduction: the concept of urban and peri-urban agriculture}

As noted by Magnusson et al. (2000), by 2050 the UN estimates that the global population will reach 9.6 billion, with the majority of that growth taking place in urban areas of less developed regions (United Nations 2012, 2013). By 2100 the population is expected to be 11.2 billion. This will lead to a huge rise in demand for resources (physical, space and infrastructure), and the number of middleclass consumers will increase by three billion. Sub-Saharan Africa constitutes a great portion of this projected growth, as the urban population is predicted to expand faster than in any other region and to double between 2010 and 2030 (FAO 2012). The rapid expansion of urban populations puts direct

(C) 2015 Aloysius Clemence Mosha. This is an Open Access article distributed under the terms of the Creative Commons Attribution 4.0 Unported (CC BY 4.0) License (https://creativecommons.org/licenses/by/4.0/), allowing third parties to copy and redistribute the material in any medium or format and to remix, transform, and build upon the material for any purpose, even commercially, provided the original work is properly cited and states its license.

Citation: Commonwealth Journal of Local Governance 2015, 18: 4842, - http://dx.doi.org/10.5130/cjlg.v0i18.4842 
pressure on food sources and agricultural production; thus there exists a serious challenge in supplying enough nutritious and safe food in a situation of such rapid urbanisation.

Despite many technological and mechanical improvements in food production, hunger and malnutrition remain central issues as poverty continues to be prevalent in many cities around the world. Specifically, it is estimated that $40 \%$ of urban inhabitants are living on less than US\$1 a day, and $70 \%$ are living on US\$2 a day (FAO 2012).

Rural dwellers moving to cities often bring their agricultural practices with them for food security and livelihood reasons (Thys et al. 2005). However, the translation of agriculture from a traditional rural industry to an urban and peri-urban phenomenon leads to significant livelihood changes. There is no universal definition of urban and peri-urban agriculture (UPA), but the term typically refers to agriculture practices - formal or informal, and within and around cities - which raise, process and distribute food from fisheries, chicken, horticulture and livestock.

UPA is used as a strategy by many urban dwellers in both developed and developing countries to improve their livelihoods and overall wellbeing. Research has shown that many households in the African continent have benefited greatly from this activity. Firstly, UPA improves a household's access to food during times of shortage, instability or uncertainty (Bush 2010; Zezza and Tasciotti 2010). Secondly, UPA can act as an income-generating activity as farmers produce directly for markets or sell their surplus, which contributes to a household's income security (Cohen and Garrett 2010; Mougeot 2005). Lastly, UPA contributes to improved health among the urban population by providing highly nutritious and fresh foods (Zezza and Tasciotti 2010).

Despite these positive aspects of food security, livelihood and access to nutritional foods, there are downsides to UPA. Some major problems are the increased risk of the spread of diseases from animals to humans, and sanitary and environmental problems related to waste, water and manure (Bonfoh et al. 2010).

It is in light of the above that this paper examines the relevance and role played by UPA in Botswana. The paper is structured as follows: background to and rationale for UPA; the experience of UPA in Botswana and its benefits to the local economy and its people; challenges and constraints encountered; and finally lessons learnt. The paper concludes by putting forward possible strategies to enable an increased uptake of this activity.

\section{Urban agriculture in Botswana: a literature review}

To date there has been only limited research on urban agriculture or urban food production in Botswana, for two main reasons. Firstly, the sector had until recently been put on the back burner by 
government, and secondly researchers and academics have not been interested in the subject as it is deemed peripheral to the main urban problems of the country.

The earliest study is that of Byerley (1996), who carried out a small research project on urban agriculture in a neighbourhood of Francistown, the second largest city in Botswana. The major finding of his study was that urban agriculture had not employed people to any significant extent in the town, for several reasons including: the harsh climate; lack of water or the prohibitive cost of water; strict urban planning regulations; cultural and attitudinal factors; relative poverty; recent urbanisation; and a preference by respondents to carry out cultivation in rural areas.

Another study on urban poverty alleviation strategies was undertaken by Mosha (1999), who found that urban agriculture was a survival strategy adopted by the urban poor. Again, however, it was found that little agriculture was actually practised, for the same reasons as those advanced by Byerley. However, it was also found that the presence of government 'safety nets' such as subsidies and handouts encouraged people to just sit by and wait for public help, leading to a 'handout' mentality (Mosha 1999).

A third research study was undertaken by Matsila (1999) on the practice of UPA in Jwaneng town. She found that: "...it is a viable survival strategy that the urban poor are beginning to engage in, though the numbers are still small." She suggested that "urban agriculture should be encouraged and assisted in raising the standard of living of the low-income [groups] in urban areas."

A fourth study was that done by Hovorka (2004), which looked at gender issues in urban agriculture in Greater Gaborone, where the activity has a predominantly commercial character and most produce is sold on the urban market. In her study she found that UPA did not emerge as a response to stifled economic opportunities in the city, but rather from a favourable political and economic environment, fuelled by government financial assistance for local businesses and urbanisation trends. She found a total of 114 commercial agricultural enterprises operating in Greater Gaborone, varying in scale and type of production.

Her research revealed that gender clearly influences the quantity and type of foodstuffs produced for the urban market. Gender matters because men and women enter into agricultural production, and participate within this urban economic sector, on unequal terms based on socio-economic status, location and interrelation with the environment.

The latest relevant study is that by Acquah et al. (2014) on urban food insecurity in Gaborone. These researchers undertook a baseline study of 400 households drawn from Old Naledi, White City/Bontleng and Broadhurst. The study found that levels of food insecurity in these areas of the city 
were high and, despite the economic health of Botswana compared to the Southern Africa Development Community (SADC) countries, no better than in many other cities. Only $12 \%$ of households were completely food-secure, while $62 \%$ were severely food-insecure. Food insecurity was endemic in the poorer parts of the city, and Botswana's 'economic miracle' was clearly not reaching many of these households.

Other relevant writings, albeit more peripheral to this subject, are those by Kruger (1994) who observed that food was very expensive in the urban areas of Botswana; and Feddema (1990) and Hesselberg (1993) who found that there is a high propensity for multi-cropping as a method of assuring food security in Botswana. They too found that there was hardly any urban agriculture in Botswana.

From these limited studies and a general observation it is obvious that UPA has not really been on the radar for Botswana's citizens, for two main reasons: one, for some time Botswana had been enjoying relatively high per capita GNP which masked the underlying poverty that the downturn of the economy has brought to the fore; and secondly, the government has been very generous in providing safety nets to poor and low-income citizens, to the extent that many people are now dependent on them for survival, rather than engaging in UPA.

\section{Research study methodology}

The present research was carried out to document the extent and impact of UPA in Botswana's cities and towns. The issue is that in spite of great efforts made both by central and local government, UPA uptake has been low despite its potential contribution to food security, poverty alleviation and employment generation - especially among women and young people.

Both quantitative and qualitative data was collected: firstly through secondary data sources including a literature review, government reports/documents and policy statements; and secondly through empirical data collection.

The empirical data collected for the study derived primarily from semi-structured interviews with key stakeholders in the five main urban centres of Gaborone, Francistown, Lobatse, Selebi Phikwe and Jwaneng. Respondents represented a wide range of stakeholders including: ministries related to land, environment, agriculture and livestock; municipal planners; agriculture and livestock extension officers (sensitization and advice on good agricultural practices); research institutions; urban farmers; civil society; and multilateral organisations. The interview questions were designed to explore the past, present and future role of UPA practices, as well as the institutionalisation and legitimisation of urban agriculture, and were structured using the following themes: typologies of UPA, organisational 
roles, collaboration and engagement in urban agriculture, allocation of space and resources for urban agriculture, main challenges associated with legitimisation/institutionalisation, future initiatives, and the role of governance.

Additionally, the researcher toured various areas where UPA was and is being practised to get firsthand experience and impressions of the various activities, which include poultry farming, beef and dairy farming, arable farming, horticulture, and the growing of flowers and other ornamental plants.

The collected information was collated, analysed and synthesised in the findings recorded and discussed below.

The significance of this research is that an improved knowledge of UPA can help popularise this economic sector and allow it to play a greater role in poverty alleviation, income generation and enhancement of food security, as is happening in urban centres elsewhere in the southern African region.

\section{Botswana}

\section{Background}

Botswana is a large country $\left(582,000 \mathrm{~km}^{2}\right)$ with a small population, estimated in 2015 at 2,105,127 (as against 2,024,787 in 2011). It is considered an upper-middle-income country, with a per capita GNP of about US\$7,734 and GDP of US\$15.37bn. However, despite this rosy picture poverty is also endemic. Rural areas had the highest concentration of households living below the poverty datum line in $2009 / 10$ at $14.5 \%$ compared to urban villages at $10.4 \%$ and cities and towns at $5.2 \%$ (Statistics Botswana 2013). Although poverty in Botswana is predominantly rural, the rate of urbanisation (8.4\% per annum) is the highest in Africa, and rural migration has led to increasing concern about social and physical changes in urban areas. In 1997, the UNDP reported that $20 \%$ of people living in urban areas in Botswana were considered 'poor' and 9\% 'very poor'. Nearly 20 years later in Gaborone, 20\% of the population is still poor and 7\% very poor (Acquah et al. 2014).

\section{Rising population growth and urbanisation}

Between independence in 1966 and 2011, the proportion of the population living in urban areas increased from 5\% to $61 \%$. The proportion has grown from $45.7 \%$ in 1991 to $61.8 \%$ in 2011, and is expected to exceed $70 \%$ in 2021 (Statistics Botswana 2010). The percentage of the national population residing in Gaborone, the capital, and its satellite communities grew from 15\% in 1981 to $25 \%$ in 2011, due to a combination of rural migration and organic growth. Food and nutrition requirements have thus risen considerably over the years in line with this rising population. 


\section{Rise in female-headed families}

The 1985/86 Household Income and Expenditure Survey revealed that 42\% of all urban households were headed by a female; in rural areas, the percentage was $46 \%$. By the time of the 1991 census, this percentage had increased to $49 \%$ nationally (GOB 1996). Today it is significantly higher. Femaleheaded households are generally poorer than male-headed households, as men have 2.6x the earning power of women in urban areas, and $1.8 \mathrm{x}$ in rural areas.

The rise of teenage mothers is one of the most disturbing dimensions of the female-headed household phenomenon. Already strained households are stretched further as the grandmother or greatgrandmother becomes the main caretaker for children. Many of these women end up working in UPA to access food and nutrition for their families.

\section{Urban unemployment and poverty}

Despite the relatively high average income per capita, Botswana is still plagued by many development problems common to low-income countries. In all the national plans since independence, the government's main goals have been poverty eradication, food sufficiency, improved nutrition and equality. These lofty ideals have proved very challenging to implement. Inequality is high, with a Gini coefficient of 0.649 in 2009/10 - compared to the widely agreed figure of 0.4 as an acceptable coefficient. On the other hand, poverty levels in Botswana have been falling steadily, from $30.6 \%$ in $2002 / 03$ to $19.3 \%$ in 2010 . Over the last 20 years, the incidence of poverty has been higher in rural areas than in urban areas (BIDPA/PEI 2012).

Table 1: Poverty trends in Botswana: snapshot of 2002/03 and 2009/10

\begin{tabular}{|l|c|c|}
\hline Location & $\mathbf{2 0 0 2 / 0 3}$ & $\mathbf{2 0 0 9 / 1 0}$ \\
\hline Towns and cities & $10.6 \%$ & $8 \%$ \\
\hline Urban villages & $25.4 \%$ & $19.9 \%$ \\
\hline Rural areas & $44.8 \%$ & $24.3 \%$ \\
\hline National & $30.6 \%$ & $19.3 \%$ \\
\hline
\end{tabular}

Source: Statistics Botswana 2010

Younger et al. (2010) found that rural households headed by farmers were just about as poor as those households whose heads were unemployed. The BIDPA/PEI study (2012) argues that poverty in Botswana can thus be addressed by an economic diversification policy that supports employment of the poor. However, supporting sustainable and efficient agricultural production could attract and absorb the less educated poor, provided agricultural wages are competitive to (minimum) wages in non-agricultural sectors.

Generally, unemployment in Botswana has been decreasing marginally, with urban areas having less unemployment than rural areas. However, in 2010 unemployment among young people was as high as 
$25 \%$. To address this problem, the government initiated several schemes and funds, including the National Service Programme, the Youth Development Fund, the Young Farmers' Fund and the Youth Empowerment Scheme.

\section{Drought}

Botswana's harsh and dry climate, coupled with several droughts in the years after independence $(1968-70 ; 1979 / 80 ; 1981 / 82 ; 1987 / 88$ and 1992/93) forced a number of people to move to urban areas in search of work and a better life, but sadly most of these people have never achieved economic success. Their only option is to engage in informal activities such as petty trading, urban agriculture etc.

\section{Economic slowdown}

During the last three years, the Botswana economy has been experiencing slow growth, which can be attributed mainly to the decline in diamond exports, on which Botswana is highly dependent. This has adversely affected government spending on major projects. The manufacturing and tourism sectors have also been hard hit, resulting in an increase in unemployment. However, there are now signs of recovery as the diamond market is slowly improving, as are several macroeconomic indicators. Nevertheless, for most poor people the situation is still gloomy.

\section{Limited economic role of agriculture}

Agriculture contributes around 2\% to Botswana's total annual GDP. Botswana's climate and soils are generally unsuitable for arable farming, with only 5\% of the country currently used for crop production. Much agriculture is based on cattle farming in the rural areas (UNDP/UNEP 2013, p. 2), although this is changing: within agricultural GDP, the share of livestock has fallen from approximately $75 \%$ to $55 \%(1991-2011)$ against an expansion of mainly horticulture, from approximately $22 \%$ to $42 \%$ over the same period (UNDP/UNEP 2013). However, government efforts to promote arable crops have not resulted in national food self-sufficiency, even though they include subsidies, educational programmes and, programmes such as the Livestock Management and Infrastructure Development Programme, funding from Botswana's Citizen Empowerment Development Agency, and Young Farmers' initiatives (encouraging young people to take up agriculture). These initiatives are hampered by lack of labour, and in some cases limited access to suitable land, especially for new entrants to farming.

\section{Existing policies/programmes favourable to UPA}

In spite of the low prevalence of UPA, the sector has received attention from both central and local government. The government of Botswana has been working towards formulating a policy on UPA since the 2000s. A first national UPA workshop was held in 2001, aimed at exploring the challenges 
and potential of this initiative, and established that UPA was compatible with national development policies and programmes at the time and could particularly enhance the country's 1991 Agricultural Development Policy. The workshop therefore recommended that a national taskforce on UPA be established to accelerate its development and ensure its inclusion in mainstream national development plans. The aim was to contribute to the diversification of the economy and the secure and healthy society envisioned in Botswana's national development framework espoused in the country's 'Vision 2016'. A second UPA workshop was held in 2003, to follow up on the recommendations of the first and to focus on integrating UPA with related policies such as food security, nutrition, and land, water and waste management. This resulted in a draft policy document.

Despite ongoing work by the Ministry of Agriculture (MOA) (seminars, workshops and public consultations; the setting up of the multi-sectoral and multi-disciplinary taskforce to push for the development and inclusion of UPA in National Development Planning processes) over ten years on the UPA policy remains a draft. The final policy framework is expected to focus on subsistence (backyard gardens) and community urban agriculture projects to address issues of household food security, which have proved very intractable over the years. Although the policy will primarily target socially disadvantaged groups such as women, children, the unemployed, and the sick and elderly, the framework will be wide enough to include other groups and encourage a 'green culture' generally among citizens. The commercial sector is also being targeted, as its contribution to the economy could be useful given the number of such farms in the peri-urban areas of Botswana (Keboneilwe and Madisa 2005).

A number of associated initiatives geared at meeting the food and nutrition objectives that also take into consideration the pandemic HIV/AIDs that has ravaged the country have also been implemented. These include:

(a) Having demonstration gardens in offices as a way of encouraging communities to develop backyard gardening;

(b) Producing booklets for vegetable production to guide individual families and communities on how to produce vegetables;

(c) Provision of formal and informal training in agricultural training centres;

(d) Provision of technical assistance on production and marketing aspects of home and community gardens to individuals, families and communities, women groups and home based care groups; and

(e) Building partnerships with NGOs and the private sector on implementing urban agriculture. 
Another successful example is the use of recycled water for agriculture. Rapid urbanisation has led to an increase in wastewater in the cities/towns of Gaborone, Francistown and the Central District, and this can be recycled for irrigation, especially in commercial urban agriculture. Current treatment plants are designed for relatively large capacities: for example the plant in Gaborone has a capacity of $48,000 \mathrm{~m}^{3} /$ day, but its inflow is only $30,000 \mathrm{~m}^{3} /$ day and its outflow $17,000 \mathrm{~m}^{3} /$ day (BIDPA/PEI 2012). There is thus spare capacity at the water treatment works, and even though plants typically collect more than $50 \%$ of their current capacity, their outflow of treated wastewater is limited, and only a small proportion is put to productive use in agriculture. Higher use of treated wastewater, particularly in agriculture, would complement the current rainwater harvesting carried out through river systems in the Tuli Block and Notwane areas, where Botswana's horticulture is concentrated.

\section{Lessons learnt}

The experiences gained by the MOA indicate that for the successful implementation of urban agriculture policies and projects it is important that:

- Participatory approaches are applied at the planning, implementation and monitoring of these policies and projects;

- Costs and benefits of urban agriculture projects should be shared by all stakeholders involved in these projects;

- Destigmatise urban agriculture projects by making them as open as possible for anyone interested in improving their nutrition. The Draft Policy Paper has chosen this strategy in order to ensure that UPA catches on without being stigmatised and/or associated with HIV/AIDs.

\section{Extent and practice of UPA in Botswana}

Urban food production is practised by a relatively small number of people in Botswana, and it appears in various forms. In this wider sense urban and peri-urban agriculture refers not only to food crops and fruit trees grown in urban centres, but also to different kinds of livestock, medicinal plants and ornamental plants.

The urban farmers of Botswana are women and men from all income groups, but the majority are low- to medium-income-earners, who grow food for self-consumption or income generation. Most cultivation is informal, with little if any support. Commercial UPA is limited to areas like Greater Gaborone, Francistown or Lobatse.

Women tend to dominate certain components of urban cultivation (backyard gardening, small-scale animal husbandry). They are still disadvantaged in the formal sector of the urban economy and therefore get involved in small- and micro-scale production. Urban food production can be relatively 
easily integrated into other household activities and women tend to hold responsibility for household food security. Men tend to dominate commercial urban food production. In some cases children are involved, mainly in weeding and watering. Urban farmers engaged in complementary production systems often cooperate with one another: for example, they may use each other's plots for different purposes at different times, and exchange wastes or products.

Urban agriculture links farm cultivation with small-scale enterprises - for example street food stands, the selling of fresh produce such as spinach, fresh milk outlets and maize roasters - and also to industries such as fencing, pumping, irrigation, processing and transportation.

\section{Reasons for participating in urban agriculture}

All sorts of people and commercial companies practise UPA for different reasons. These include enjoyment of the activity, food security, better nutrition, employment, poverty alleviation and others. A summary of these motivations has been captured in a study by Mosha (2001a) in the city of Gaborone:

(a) For many smallholder/on-plot households, especially female household respondents, participation was purely a survival strategy. Most engaged in UPA to supplement their meagre incomes (whatever the source), which were too low to sustain their needs. By engaging in this activity they could feed themselves and their families. In the study, $35 \%$ of respondents produced solely for home consumption, while $61 \%$ sold the surplus to supplement their incomes. The remainder, 4\%, exchanged or bartered their vegetables and other products. The selling of produce was mainly within the neighbourhood, to individual households rather than institutions, supermarkets or vendors. Some producers encountered marketing problems such as competition, lack of proper markets, slow sales, defaults on credit sales and fluctuating prices. Some also complained of having gardens which were too small to allow increased production.

(b) For those who were keeping poultry at the Gaborone Dam site the activity was an economic venture aimed at amassing wealth. They sold their produce to institutions, supermarkets and wholesalers. Little was sold to individuals.

(c) Some respondents said the fruits and vegetables in the city's supermarkets were too expensive for them. Also, these products were not always fresh as they were imported from South Africa.

(d) For a few respondents, especially those in high-income households, urban agriculture was practised for pleasure and to pass the time. 


\section{Extent}

It is important to point out that there is no readily available disaggregated data on the extent of UPA in Botswana; therefore it is difficult to provide exact figures on its contribution to the urban economy or to food and nutrition in the community. However, occasionally data is available and demonstrates the vital role of this sector. For example, a UNDP report has indicated that data from the Ministry of Agriculture shows that horticultural yields per hectare in peri-urban areas rose dramatically from 1997/98 to 2007/08, which indicates high potential for this sub-sector if appropriate support and focus is provided (UNDP/UNEP 2013, p. 2). Yields rose from 5 metric tons/ha in 1997/98 to 35 metric tons/ha in 2007/08 (BIDPA/PEI 2012).

The studies mentioned so far in the paper, for example those by Mosha (1999), Byerley (1996) and Hovorka (2004) and by some other authors like Madisa and Assefa (2011), Lekobane and Seleka (2011), Emongor and Ramolemana (2004) indicate that UPA has not been embraced in Botswana as much as in other countries in the sub-region. At present, only limited agriculture is practised: in the form of small livestock, poultry, pig-farming or arable farming on a very small scale in residential areas; or much larger activities along river valleys traversing the major towns; or on the many freehold farms found in peri-urban areas.

Many researchers have associated the growth of urban agriculture with economic hardship, but in Botswana UPA practice has not caught on even among the poorer segments of the population. Findings by Mosha (2001a) indicate that the country's strong economic base, as well as its extensive welfare programmes, are possible reasons for this. This is corroborated by an AFSUN survey carried out in Gaborone recently, which found that supermarkets are easily the most important food source for the urban poor, with $92 \%$ of households using them as a normal food source. Only 5\% of households cited UPA as their main food source, and the survey found that the informal food economy is relatively unimportant for the majority of poor urban households. Only $29 \%$ of households said they normally obtained food from informal sources, and just $23 \%$ had done so in the previous week - and most of that was consumption of cooked street food during the day. As many as $71 \%$ of households never obtain food from informal sources. Other studies (eg Acquah et al. 2014) have found that the informal food economy and small retail outlets are far less important in Gaborone than in most other cities. Around half of Gaborone households obtain food from this source on a regular basis, compared with a regional average of $68 \%$. As many as $43 \%$ of Gaborone households never obtain food from small outlets. 
Table 2: Sources of food in Gaborone City in 2014

\begin{tabular}{|l|c|c|}
\hline Source & $\begin{array}{c}\text { Normal source } \\
\text { (\% of households) }\end{array}$ & $\begin{array}{c}\text { In previous week } \\
\text { (\% of households) }\end{array}$ \\
\hline Supermarkets & 92 & 73 \\
\hline Small outlets & 54 & 52 \\
\hline Informal food economy & 29 & 23 \\
\hline Urban agriculture & $\mathbf{5}$ & $\mathbf{2}$ \\
\hline Food aid & 5 & 5 \\
\hline Food remittances & 4 & 4 \\
\hline Sharing meals with neighbours/other households & 21 & 16 \\
\hline Food from neighbours/ other households & 21 & 18 \\
\hline Borrow food from others & 4 & 3 \\
\hline
\end{tabular}

Source: Acquah et al. 2014, p. 223

\section{Types of UPA activities}

In Botswana, four main types of UPA are practised: backyard gardening and keeping of poultry and small animals such as rabbits (ie family on-plot farming); demarcated plots along dams, rivers etc (individual or group operators); intensive activities in tribal peri-urban areas such as Kazungula, Tlokweng and Mogoditshane; and institutional agricultural programmes/projects (eg in schools, prisons, BDF etc).

\section{Backyard gardening}

Although on-plot urban farming has been practised for some time, its profile soared when the current president of Botswana, Lt. General Khama Ian Kgama, launched a nationwide backyard gardening scheme in 2009. Under this government initiative, deserving individuals are identified and given help to start a backyard garden. The help involves provision of basic infrastructure and skill development for beneficiaries, with the goal of small-scale production of vegetables. Participants are provided with irrigation systems, seeds, fertilisers and garden tools. Similar packages of support are also available for production in workplaces where there are demonstration plots.

According to the director of the government agency Poverty Eradication, 317 people to date have embraced and benefited from the programme around the country. This figure stands in marked contrast to the government's target, which was to establish c.12,800 backyard gardens by the end of 2011/12. Uptake has thus clearly been very slow, partly due to lack of commitment by farmers, but in urban areas like Gaborone the programme has also been hit hard by the current water shortages, which have resulted in water rationing which is not expected to end anytime soon.

A variety of produce comes out of UPA. In the study on Gaborone, the majority of those who practised on-plot farming planted vegetables like rape and chomoliah (27\%), spinach (17\%), tomatoes (14\%), maize and cabbage on a small plot beside their house, mostly during the rainy season (summer 
months). In addition most homes had a variety of fruit trees including peaches, guava, orange, lemon and pawpaw, as well as strawberries and the like. Most produce was for own consumption to cut their food bill. Poultry-keeping was mostly confined to the dam site, in purpose-built chicken houses. Some chickens, however, were kept on-plot either in cages or free-range, especially in the squatter area of Naledi and in the Self-Help Housing Areas (SHHA) areas (Mosha 2001b).

\section{Land within urban areas}

In all urban centres various UPA activities are carried out, either in zoned areas along river valleys, on open spaces, as on-plot farming or in dams (fish farming). In Gaborone, for example, of the total land area of 19,096 ha within the city in 1998, agricultural land/forestry occupied 2,468.12 ha, or 18 plots, amounting to $17.09 \%$ of the total land area. This includes areas such as the Segoditshane and Notwane rivers.

\section{Commercial UPA}

In some urban centres such as Gaborone, Francistown, Maun etc, UPA is carried out on a commercial scale in peri-urban areas, in both freehold and tribal farms. The main activities are poultry-keeping and piggeries, as well as growing of vegetables such as cabbages and spinach. Hovorka's (2004) study found that in the peri-urban areas of Greater Gaborone UPA operations were formally recognised, often initiated by government grants like the Citizen Empowerment Development Agency (CEDA), in contrast to many other African contexts where urban agriculture is an informal activity. In her study $74 \%$ of these operations were found to be registered as companies. The remaining enterprises operated within the informal sector yet remained income operations rather than subsistence farms. An equal number of men and women participate in this economic sector, with $44 \%$ of these enterprises being male-owned and operated, 47\% female-owned and operated, and 9\% male/female co-owned and operated. This is an important finding given that in other African contexts women are often relegated to subsistence realms while men predominate in commercial activities.

\section{Institutional UPA}

UPA in Botswana is also practised by government institutions such as schools, colleges, the army or the Prisons Department. Much of the produce is for own use, although sometimes for sale or for research. For example in Gaborone the Botswana College of Agriculture established in 1991, has a big chunk of land that it uses for both livestock and horticulture research. The undeveloped part of Sowenflat 2-KO, south of Phakalane Estates, is to be used for an agricultural irrigation project which has teaching and research components. The project is expected to utilise the improved quality effluent from the nearby activated sludge treatment works. 


\section{Sale of produce}

For commercial produce like chicken, cabbages and tomatoes, farmers have established markets with the supermarkets/wholesalers in the urban centres, or sell to individuals either on-plot or by petty trading. For small-scale on-plot farmers, any surplus food is sold mostly on the plot, in front of shops in town, from small pick-up trucks, and on street corners/open spaces; or sometimes in offices. The advantage of selling on-plot is that farmers save on transport costs. However, not much money is made from such sales.

\section{Income from sold produce}

It is difficult to assess overall income from produce, as there are no reliable statistics. Obviously income from UPA varies greatly depending whether it is carried out for own use or for commercial purposes. Taking as an example the commercial production of chicken, Acquah et al's 2014 survey found that the price varied from 7-10 pula/kg, and egg prices ranged from 3.95-4.50 pula/dozen. On the whole, during the survey in Gaborone, gross annual incomes among those keeping poultry at the dam site ranged from 200,000 pula to 700,000 pula, depending on the number of birds kept.

\section{Challenges facing UPA and possible solutions Negative attitudes/perceptions}

According to respondents in Gaborone, there was a strong perception among respondents that the urban and peri-urban areas of Botswana are unsuitable for agriculture. Many concerns (eg pollution, competition for resources etc) stem from a heightened appreciation and awareness of environmental issues by the general population. Although similar concerns do arise in rural agricultural production, two important reasons make them more acute in the urban environment: proximity to greater numbers of people, and already-high stresses on the urban natural resource base.

A subtle challenge to commercial urban agriculture stems from wider perceptions of this activity amongst key stakeholders in Botswana, which reflect the discourse promoted by international development organisations rather than what is actually happening at local level in, for example, Greater Gaborone. This is also confirmed by the study by Wilbers et al. (2004) which showed that key stakeholders interviewed for her research also do not distinguish between subsistence and entrepreneurial urban agriculture, and consequently pay little attention to the latter form of this activity in Greater Gaborone. So, although urban agricultural enterprises are formally recognised in Botswana, the activity, and particularly its commercial form and function, remains relatively invisible and its contributions to urban food security and economic diversification and growth remain unrecognised. 
Along with this discrepancy between perceptions and empirical evidence, there were also some underlying preconceptions amongst respondents in the study towns and cities about what type of agricultural activities 'belong' in the city. While key stakeholders embrace certain sub-sectors, they shun others they consider undesirable. For example, the original plan for the Glen Valley horticultural site in Gaborone City included horticulture, piggery and poultry operations. At a committee meeting held in June 2001, however, pigs and poultry were deemed unacceptable by those in attendance. There has also been debate concerning the poultry operations at Gaborone Dam, in particular concerning the issue of waste disposal and disease management. This debate on the merits and demerits of using sewage water has largely been driven by Gaborone residents. All in all, a particular 'vision' of urban agriculture emerges from discussions with key stakeholders and urban dwellers, and is influencing planning and policy-making.

\section{Environmental concerns}

As indicated earlier, the major threats to health and the environment from agricultural production systems in urban and peri-urban areas arise from inappropriate or excessive use of agricultural inputs (eg pesticides, herbicides, fumigants and fertilisers). To add to this is also the issue of safe disposal of livestock effluent in and around cities and towns. Numerous health concerns/risks of this type have been associated with urban and peri-urban agriculture. Contamination of crops with pathogens usually happens when improperly treated organic waste is used as a soil conditioner. The health concerns arise when the pathogenic organisms survive compost treatment and when the compost heap is not properly maintained. Serious health problems may also arise when improperly treated wastewater is used for irrigation. This wastewater then contains various pathogens, such as bacteria, protozoa, viruses and helminthes. Activated sludge treatment plants are notorious for their poor nutrient retention and therefore treated wastewater from these plants supports microbial growth, which can quickly exceed the guidelines for safe irrigation. Extra care needs to be taken in regularly monitoring the quality of the effluent. The choice of crops to be irrigated using this kind of water is also a key factor in safeguarding public health. It is inappropriate, for instance, to irrigate fresh salad vegetables such as cabbage, lettuce, tomato etc with treated effluent.

Agricultural activity is also known to attract disease-transmitting vectors such as mosquitoes. The adaptive ability of malaria-transmitting mosquitoes is well documented. Anopheles gambiae, for instance, is said to have a preference for peripheries of cities, where it breeds in uncovered water tanks and temporary pools of clear sunlit and shallow standing water.

Air pollutants (eg carbon dioxide and methane from organic matter, ammonia, nitrous oxide and nitrogen oxide from nitrates) and other gaseous emissions that contribute to global climate change may also be an issue in UPA. 
Finally, odour and noise from UPA can also prove a nuisance, especially in residential areas.

\section{Water issues}

Water scarcity sometimes leads to conflict between demand for human consumption, especially in urban areas, and agricultural uses - with agriculture generally losing out. Many urban centres, especially those in the east of the country, are now suffering extreme water shortages that have led to water rationing for months on end. Adequate supplies of water are critical to the successful integration of UPA into the urban environment. It is important to acknowledge that water problems and food problems are connected. Even though UPA can use treated wastewater, the practice still requires good-quality and adequate water if it is to be successful in addressing food security and nutrition. In Botswana water is a finite and scarce resource, and the country therefore needs to look seriously at water-saving technologies where institutional UPA (e.g. roof water harvesting) programmes are involved. Space for UPA is available; priority should now be given to improved water performance.

Water harvesting and conservation practices are very important, particularly in a country like Botswana where horticultural crops cannot be grown successfully without irrigation. The requirement for clean, hygienic water for UPA activities puts pressure on the limited available water, which has to be shared between many uses. To date, water harvesting in Botswana has not been fully exploited. For example, harvesting from rooftops should be encouraged for irrigating backyard gardens, and would greatly reduce the cost of producing vegetables compared to using potable water.

Many farmers in and around urban centres have developed their own water sources, particularly boreholes, to satisfy their needs. They do this mainly because there is no policy to regulate the provision of raw water for agricultural purposes; or because, in areas where institutions are mandated to supply water, the tariffs are high. Some local organisations have, however, developed water-saving technologies: for example drip irrigation systems, water harvesting, water recycling and other water conservation approaches.

Dams can also be used as water catchment points and this water channelled to agricultural use, but unfortunately the only dams currently doing this are far from urban centres - hence the cost of transporting the water to the farms, and subsequently the produce to the markets, is high.

The most viable source of water for UPA may prove to be reclaimed wastewater. It is estimated that typical wastewater effluent from domestic sources, when appropriately treated for agricultural reuse, could supply all of the nitrogen and much of the phosphorus and potassium normally required for agricultural crop production. 


\section{Land issues}

Another major challenge to the viability of UPA is land availability and access. Rapidly changing land rights and uses influence UPA. High population densities also give rise to competition and conflicts over land and natural resources through agricultural intensification on the scarce spaces available for cultivation.

Also looming over many urban farmers, both men and women, is the constant threat of losing access to their plots and being forced to stop farming as towns expand. The transient nature of occupancy of urban plots can make individuals reluctant to engage in farming activities, since their residency on their plots may not be secure.

Poor agricultural techniques, such as a failure to conserve soil and water, and cultivation in marginal and sensitive areas such as riverbanks and road reservations, may also have negative impacts.

\section{Inadequate extension support}

Agricultural extension and training in Botswana has to date mainly been confined to rural and commercial farmers. There are no urban agricultural officers or urban agricultural demonstrators to parallel the district agricultural officers and agricultural demonstrators found in rural areas.

\section{Lack of access to credit}

Urban agriculture is increasingly recognised as a vehicle for the development of more productive, sustainable and inclusive or democratic cities. However, most urban agricultural producers in Botswana are from poor backgrounds, and thus have limited access to credit and investment schemes. As observed earlier, lack of access to affordable capital hinders urban producers' ability to acquire materials, tools and equipment to increase productivity. It also makes it too risky for them to invest in resource-conserving techniques and high-value crops and livestock. Providing financial support to urban farmers is generally seen by credit institutions such as banks as too risky, due to high transaction costs and lack of creditworthiness.

\section{Lack of data}

The extent of the contribution of UPA to Botswana's economy is unclear as the number of producers, quantities produced, costs and prices, incomes achieved and inputs used are not known. Nor has the impact of UPA on the environment been fully studied.

\section{Conclusion}

The findings discussed above clearly show that encouraging agricultural development in urban and peri-urban areas is a valuable strategy to promote food security, economic development, poverty alleviation and diversification within Botswana's agriculture sector. The outputs from horticulture, 
and poultry-keeping also have the potential to add further economic value in the form of jobs in the marketing, transport, storage, packaging and retail sectors.

The promotion of commercial horticulture, poultry-keeping and the raising of small livestock in the peripheries of cities and rural towns will inevitably lead to increases in land values. Policy instruments should therefore be developed to ensure such land remains affordable and available for UPA, particularly in those areas where it is geographically feasible and cost-effective to access treated wastewater.

The success of the UPA sector will depend on recognition of its monetary as well as nutritional value by all stakeholders in the urban sphere. Central and especially local government can play a key role in promoting urban agriculture, firstly by legitimisation and institutionalisation of the practice, and secondly by providing land and infrastructure. However, this should not be a top-down process, but a multi-stakeholder activity that supports the many functions (poverty alleviation, source of incomes, employment creation, nutrition to the body etc) of urban agriculture. Policy development should be holistic in nature, not precautionary. All stakeholders - public and private - should be roped in for UPA to succeed. Local and central government should also encourage 'bottom-up' or grassroots involvement in the provision of, conservation of, and access to space allocated to urban agriculture.

Such central and local government support for urban agriculture in the cities of Botswana will encourage long-term sustainability through the creation of a more integrated agriculture system.

Focus should be put on making land available for UPA; this is a priority area for focus, in which both central and local authorities should play a key role by zoning and allocating plots for UPA.

There is a need to extend training and extension to urban farmers to stimulate interest and awareness in UPA. This will improve the technical competence of farmers, their farm management skills and their marketing. Furthermore, current agricultural personnel are not trained for urban agriculture's peculiar situation; therefore there is a need to retrain staff to cater for UPA.

Financial support, whether from public sources or commercial banks, should be sought to encourage the uptake of UPA. Financial support can make a significant difference to poor urban families, who increasingly live around the poverty line, and are involved in a diversity of economic activities such as waste collection, trading and farming. Urban gardening is an indicator of political and social stability, and a survival strategy for urban inhabitants. It also helps alleviate urban poverty by improving food security, and provides job opportunities, healthy food and a recreational focus for young people. This paper therefore recommends that the government should invest in facilities and infrastructure for community gardens. 
Finally, the dearth of data on UPA should be addressed. Baseline studies are needed to assess the contribution of UPA, the inputs it requires and its impact on the environment. There is also a need for research and monitoring on UPA activities to design relevant government interventions.

\section{References}

Acquah, B., Kapunda, S. and Legwegoh, A. (2014) The dimensions of urban food insecurity in Gaborone, Botswana. Published online: 16 January 2014, Springer Science+Business Media Dordrecht.

BIDPA/PEI. (2012) Economic study: Vegetable production using treated waste water. Gaborone: PEI Botswana.

Bonfoh, B., Schwabenbauer, K., Wallinga, D., Hartung, J., Schelling, E., Zinsstag, J., Meslin, F.X., Tschopp, R., Ayayi Akakpo, J. and Tanner, M. (2010) Human health hazards associated with livestock production. In: Steinfeld, H., Mooney, H.A., Schneider, F. and Neville, L.E. (eds) Livestock in a changing landscape, Volume 1: Drivers, consequences, and responses. (pp. 197-219) Washington D.C., USA: Island Press.

Bush, R. (2010) Food riots: Poverty, power and protest. Journal of Agrarian Change, 10 (1), 119-129. doi: http://dx.doi.org/10.1111/j.1471-0366.2009.00253.x

Byerley, A. (1996) Urban agriculture in Botswana: A preliminary investigation of extent, issues and potential. Working Paper no. 307. Uppsala, Sweden. University of Agricultural Sciences, International Rural Development Centre.

Cohen, M. and Garrett, J. (2010) The food price crisis and urban food (in) security. Environment and Urbanization, 22 (2), 467-482. doi: http://dx.doi.org/10.1177/0956247810380375

Emongor, V.E. and Ramolemana, G.M. (2004) Treated sewage effluent (water) potential to be used for horticultural production in Botswana. Physics and Chemistry of the Earth, 29 (15-18), 1101-1108. doi: http://dx.doi.org/10.1016/j.pce.2004.08.003

FAO. (2012) Growing greener cities in Africa. First status report on urban and peri-urban horticulture in Africa. Food and Agriculture Organization of the United Nations. Available from http://www.fao.org/docrep/016/i3002e/i3002e.pdf

Feddema, D.B.A (1990) Survival through Cupertino in Naledi. Occasional Paper No. 4. Gaborone, Botswana: The Botswana Society.

GoB. (1996) Gaborone City Master Plan. Gaborone, Botswana: Ministry of Local Government, Lands and Housing, Government Printer.

Hesselberg, J. (1993) Urban low income groups economic strategies and linkages to rural areas: The case of Francistown. In: Dahl, J., Drakakis-Smith, D. and Narman, A. (eds) Land, food and basic needs in developing countries. Gothenburg: University of Gothenburg.

Hovorka, A.J. (2004) Entrepreneurial opportunities in Botswana: Shaping urban agriculture discourse. Journal of Contemporary African Studies, 22 (3), 367-388. doi: http://dx.doi.org/10.1080/0258900042000283511

Keboneilwe, D.L. and Madisa, M.E. (2005) Policy development and implementation by MOA. Paper presented at a workshop on Urban Micro-Farming and HIV-AIDS, Johannesburg 15-26 August 2005.

Kruger, F. (1994) Urbanisation and vulnerable urban groups in Gaborone. GeoJournal, 34 (3), 293-297. doi: http://dx.doi.org/10.1007/BF00813932

Lekobane, K.R. and Seleka, T.B. (2011) Do public transfers discourage farmer participation in subsistence crop production? Empirical evidence from Botswana. BIDPA Working Paper No. 29, Gaborone, Botswana.

Madisa, M.E and Assefa, Y. (2011) Impact of government financial incentives on peri-urban vegetable production in Botswana. Journal of Horticulture and Forestry, 3 (8), 264-289.

Magnusson, U., Bergman., K.F and Katunguka-Rwakishaya, E. (2000) Introduction to urban and peri-urban agriculture for food security. In: Magnusson, U. and Bergman, K.F. (eds) Urban and peri-urban 
agriculture for food security in low income countries - challenges and knowledge gaps (pp. 4-5).SLUGlobal Report. Uppsala: Sweden. Swedish University of Agricultural Sciences.

Matsila, G. (1999) Urban agriculture - A survival strategy for the urban poor. Case Study, Jwaneng, Botswana. Unpublished thesis, University of Botswana.

Mosha, A.C. (1999) The practice of urban agriculture in Gaborone, Botswana. Department of Environmental Science. Unpublished Research paper, University of Botswana.

Mosha, A.C. (2001a) Incorporating urban agriculture in Gaborone City Planning. Urban Agriculture Magazine no 4, July 2001

Mosha A.C. (2001b) Urban agriculture in Botswana: Challenges and prospects. In: Proceedings of the National Workshop on Peri-urban Agriculture. May 28-29 2001 National Veterinary Laboratory, Sebele. Botswana: Ministry of Agriculture, Government of Botswana.

Mougeot, L. (2005) Agropolis - the social, political and environmental dimension of urban agriculture. Ottawa, ON: International Development Research Centre.

Statistics Botswana. (2010) Botswana core welfare indicator survey 2009/10. Stats Brief 2010. Gaborone

Statistics Botswana. (2013) Botswana core welfare indicator survey 2009/10. Stats Brief July 2013. Gaborone

Thys, E., Oueadraogo, M., Speybroeck, N. and Geerts, S. (2005) Socio-economic determinants of urban household livestock keeping in semi-arid Western Africa. Journal of Arid Environments, 63 (2), 475 496. doi: http://dx.doi.org/10.1016/j.jaridenv.2005.03.019

UNDP/UNEP. (2013) Arable agriculture and the case of peri-urban horticulture in Botswana. Policy Brief. Nairobi, Kenya: Poverty-Environment Initiative.

United Nations. (2012) World urbanizations prospects, the 2011 revision: Highlights. New York: Department of Economic and Social Affairs, Population Division.

United Nations. (2013) World population prospects: the 2012 revision. Volume II: Demographic profiles. New York: Department of Economic and Social Affairs, Population Division.

Wilbers, J., Hovorka, A.J. and van Veenhuizen, R. (2004) Gender and urban agriculture. Urban Agriculture Magazine, No 12, pp. 6-7. Available at: http://www.ruaf.org/magazine-12/editorial-gender-and-urbanagriculture

Younger, S., Moepeng, P. and Siphambe, H. (2010) Consultancy report reviewing the national strategy for poverty reduction: Policies and programmes for economic diversification, employment and poverty reduction. Gaborone: UNDP.

Zezza, A. and Tasciotti, L. (2010) Urban agriculture, poverty, and food security: Empirical evidence from a sample of developing countries. Food Policy, 35 (4), 265-273. doi: http://dx.doi.org/10.1016/j.foodpol.2010.04.007 